\title{
Exercise training and endothelial function in patients with type 2 diabetes: a meta-analysis
}

\author{
Shanhu Qiu', Xue Cai ${ }^{1}$, Han Yin' ${ }^{1}$, Zilin Sun ${ }^{1 *} \mathbb{0}$, Martina Zügel ${ }^{2}$, Jürgen Michael Steinacker ${ }^{2}$ \\ and Uwe Schumann²
}

\begin{abstract}
Background and aims: Exercise training is considered a cornerstone in the management of type 2 diabetes, which is associated with impaired endothelial function. However, the association of exercise training with endothelial function in type 2 diabetes patients has not been fully understood. This meta-analysis aimed to investigate their associations with focus on exercise types.
\end{abstract}

Methods: Databases were searched up to January 2018 for studies evaluating the influences of exercise training with durations $\geq 8$ weeks on endothelial function assessed by flow-mediated dilation (FMD) among type 2 diabetes patients or between type 2 diabetics and non-diabetics. Data were pooled using random-effects models to obtain the weighted mean differences (WMDs) and 95\% confidence intervals (Cls).

Results: Sixteen databases were included. Exercise training resulted in an overall improvement in FMD by $1.77 \%$ (95\% Cl 0.94-2.59\%) in type 2 diabetes patients. Specifically, both aerobic and combined aerobic and resistance exercise increased FMD by $1.21 \%$ (95\% Cl $0.23-2.19 \%$ ) and 2.49\% (95\% Cl 1.17-3.81\%), respectively; but resistance exercise only showed a trend. High-intensity interval aerobic exercise did not significantly improve FMD over moderate-intensity continuous exercise. Notably, the improvement in FMD among type 2 diabetes patients was smaller compared with non-diabetics in response to exercise training (WMD $-0.72 \%, 95 \% \mathrm{Cl}-1.36$ to $-0.08 \%$ ) or specifically to aerobic exercise (WMD $-0.65 \%, 95 \% \mathrm{Cl}-1.31$ to $0.01 \%)$.

Conclusions: Exercise training, in particular aerobic and combined exercise, improves endothelial function in type 2 diabetes patients, but such an improvement appears to be weakened compared with non-diabetics.

Trial registration PROSPERO CRD42018087376

Keywords: Exercise training, Endothelial function, Flow-mediated dilation, Type 2 diabetes

\section{Introduction}

The endothelium, a monolayer of cells that provides a physical barrier between vessel lumen and vascular wall, is essential in maintaining vascular homeostasis, a process which is recognized to be primarily modulated via its release of a list of mediators that regulate blood coagulation and vascular tone [1-3]. Endothelial dysfunction is referred to the condition where the endothelium loses

\footnotetext{
*Correspondence: sunzilin1963@126.com

${ }^{1}$ Department of Endocrinology, Zhongda Hospital, Institute of Diabetes, School of Medicine, Southeast University, Nanjing, People's Republic of China

Full list of author information is available at the end of the article
}

its physiological properties but shows a tendency towards vasoconstriction, pro-thrombotic, and pro-inflammatory states [2, 3]. In addition to being a well-recognized precursor of atherosclerosis $[4,5]$, endothelial dysfunction has also been considered a pathophysiological hallmark characterized by type 2 diabetes [3]. This originates in the evidence that endothelial dysfunction is consistently observed in patients with type 2 diabetes [5-7] and predicts the risk of incident type 2 diabetes [8]. On the other hand, endothelial dysfunction is recognized to be an initiating and important factor in the development and progression of diabetes related microvascular and macrovascular complications $[5,9]$.

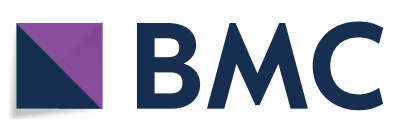

(c) The Author(s) 2018. This article is distributed under the terms of the Creative Commons Attribution 4.0 International License (http://creativecommons.org/licenses/by/4.0/), which permits unrestricted use, distribution, and reproduction in any medium, provided you give appropriate credit to the original author(s) and the source, provide a link to the Creative Commons license, and indicate if changes were made. The Creative Commons Public Domain Dedication waiver (http://creativecommons.org/ publicdomain/zero/1.0/) applies to the data made available in this article, unless otherwise stated. 
Since exercise training is a key element in the management of type 2 diabetes [10-14], and given that endothelial dysfunction might be a therapeutic target for diabetes $[14,15]$, there is a growing interest in exploring the influence of exercise training on endothelial function in patients with type 2 diabetes [16-24]. However, available studies on this topic have shown inconsistent and inconclusive findings. Some randomized controlled trials (RCTs) have indicated that exercise training improves endothelial function, while others noted that it may not. Moreover, most of these studies had small sample sizes [17-19, 21-23], ranging from 13 to 39. Noteworthy, Montero and colleagues conducted a meta-analysis with enhanced statistical power in 2013 pointing out that in patients with type 2 diabetes exercise training increased flow-mediated dilation (FMD) - a non-invasive but the most widely used approach for endothelial function assessment [25], but their conclusion was based on five RCTs from four articles [26] while more related RCTs were published since then $[18,22,24]$. Furthermore, the authors did not assess the influences of different exercise training types (e.g., aerobic, resistance, or combined training) on endothelial function, nor explored the potential moderators (e.g., glycemic control, blood pressure, or cardiorespiratory fitness) in predicting the changes in endothelial function related to exercise training, possibly because of the limited number of studies available at that time.

Therefore, we conducted this meta-analysis by incorporating the latest evidence with a primary focus on the impacts of exercise training and exercise types on endothelial function assessed by FMD in patients with type 2 diabetes as well as on the investigation of their potential moderators. Moreover, since endothelial function is evidentially impaired in patients with type 2 diabetes compared with non-diabetic controls $[5,6]$, our secondary aim was to assess whether the presence of type 2 diabetes would attenuate the improvement in endothelial function in response to exercise training.

\section{Methods}

This meta-analysis is reported following the Preferred Reporting Items for Systematic Reviews and Meta-Analyses (PRISMA) guideline [27], with its protocol registered in PROPERO as CRD42018087376.

\section{Search strategy and study selection}

A systematic literature search for relevant studies published in English was conducted in the databases of PubMed, the Cochrane Central Register of Controlled Trials, and Web of Science from their inceptions to January 12nd, 2018. In addition, the reference lists of relevant articles, reviews, and meta-analyses were manually checked for other suitable studies. The words or terms used for searching were linked with "endothelial function", "diabetes", and "exercise training" (see Additional file 1: Table S1).

Studies eligible for inclusion in this meta-analysis required to fulfill the following criteria: (i) participants were diagnosed with type 2 diabetes; (ii) the intervention groups received land-based normoxic exercise training programs with durations $\geq 8$ weeks, a time-window which is commonly employed to assess the chronic exercise training effects on health outcomes [28]; (iii) the controls received no exercise (or usual care), exercise training programs different from the intervention groups, or non-exercise intervention programs comparable to the intervention groups; (iv) outcomes on endothelial function assessed by FMD had to be reported pre- and post-intervention; and (v) allocation to the intervention or control group should be random. Studies were also considered eligible if they compared the effects of exercise training with durations $\geq 8$ weeks on endothelial function assessed by FMD in patients with type 2 diabetes versus non-diabetes controls. Studies were excluded if they were posters or protocols, had a lack of proper controls, or did not report outcomes on FMD.

Two authors (S.Q. and X.C.) reviewed the titles, abstracts, and/or full-texts for each of the articles identified by the literature search after removal of duplicates, aiming to determine the eligibility for this meta-analysis. During the study selection process, discrepancies were resolved by discussion with a third author (U.S. or Z.S).

\section{Data extraction and quality assessment}

A standardized data abstraction form was applied to collect the following information from eligible studies: author information, participant characteristics [including sex distribution (proportion of males), duration of diabetes, and the means of age, body mass index (BMI), blood pressure, glycemic control, and cardiorespiratory fitness at baseline], intervention details (including type of exercise, intensity, time for one bout of exercise, frequency, and intervention duration), and study outcomes (including FMD at baseline and post-intervention). If the outcomes of interest were incomplete or could not be imputed, corresponding authors of the original studies were contacted via emails. Moreover, in this meta-analysis FMD was calculated as the percent change in diameters following reactive hyperemia compared with the baseline diameters at rest.

The Cochrane Collaboration "Risk of Bias" tool [29], which includes items on selection bias, performance bias, detection bias, attrition bias, and reporting bias, was applied to evaluate the quality of eligible studies. All the data collection and quality assessment were initially done 
by one author (S.Q.), and later checked by another author (X.C.). Discrepancies, if occurred, were resolved by referring back to the original studies.

\section{Data synthesis and statistical analysis}

For studies reporting standard errors, 95\% confidence intervals (CIs), or interquartile ranges, the standard deviations were obtained using the methods described in Cochrane Handbook for Systematic Reviews [29] or reported previously [30]. For studies including two different exercise training interventions, the control group was split into two groups with smaller sample sizes, aiming to provide reasonably independent comparisons and to overcome the unit-of-analysis error [29]. Post-intervention FMD values were primarily chosen for analysis in general, but only the change scores from baseline were selected for assessing the impact of the existence of type 2 diabetes on endothelial function in response to exercise training, which is because the baseline FMD results were not comparable between type 2 diabetes patients and non-diabetes controls.

The weighted mean differences (WMDs) with 95\% CIs were calculated using a random-effects model, which seems to better account for between-study heterogeneity and could provide more conservative results than a fixed-effects model [29]. The heterogeneity was evaluated using the $I^{2}$ statistic, with the value $>50 \%$ indicative of significant heterogeneity [29]. Subgroup analysis was conducted to investigate the impact of exercise types on endothelial function, and meta-regression analyses were undertaken to assess the influence of patient and intervention characteristics in moderating changes in endothelial function. Sensitivity analyses were performed to assess the robustness of the findings by restricting the analyses to studies using exercise training as the sole intervention, reporting no or only minor changes in medication use during the intervention periods, or employing the intention-to-treat analysis. Publication bias was evaluated using the Begg's and Egger's tests, with the $P<0.10$ indicative of significance [29]. All the analyses were conducted using STATA software (Version 12.0, StataCorp LP, College Station, Texas). A 2 -sided $P<0.05$ was considered statistically significant unless otherwise indicated.

\section{Results}

\section{Literature search and study characteristics}

The literature search result and study selection process are shown in Fig. 1. Of the 3136 unique articles identified, 77 were searched for full-text assessment after screening of titles and/or abstracts, with 12 considered eligible for inclusion [16-24, 31-33]. Since two articles had two different exercise training protocols with a non-exercise control group, providing three independent comparisons for each $[17,18]$, a total of 16 studies (databases) were finally included.

The main characteristics of participants and exercise interventions are presented in Table 1 . There were 477 participants enrolled in the 16 studies, of which 13 explored the effects of exercise training on endothelial function in type 2 diabetes patients, and the remaining three assessed the influence of the presence of type 2 diabetes on the improvement in endothelial function related to exercise training. Among studies with available information, the mean age of type 2 diabetes patients was 54.2 years, the BMI was $30.0 \mathrm{~kg} /$ $\mathrm{m}^{2}$, and the duration of diabetes was 8.9 years. None of the included studies provided information on creatinine levels or estimated glomerular filtration rates, but nearly half of them had indicated the exclusion of patients with chronic kidney diseases $[16,18,19,21,23$, 24]. There were no changes in medication use throughout the intervention periods in most studies that assessed exercise training effects on endothelial function in type 2 diabetes patients [16-18, 21-23].

Of the 16 studies included, the durations of exercise interventions ranged from 8 to 26 weeks, with the majority being 12 weeks; and the frequency of exercise varied from 3 to 5 times/week. The intensity for aerobic exercise was moderate to vigorous in general based on the position statement on physical activity and exercise intensity by Norton and colleagues [34]. The time for one session of aerobic exercise ranged from 20 to $60 \mathrm{~min}$. For resistance exercise, it was composed of 2-3 sets ranging from 10 to 15 repetitions; however, its intensity was generally not well defined except three reported to be $50-70 \%$ of one repetition maximum. There was one study adding a moderate energyrestricted dietary program [19] and another one adding standard care [22] to both the intervention and control groups.

The approaches for assessing FMD were well described in each individual study except the one by HollekimStrand and colleagues [24]. All participants were required to be fasted for measuring FMD. The cuff was frequently placed at the upper-arm in FMD measurement procedures, with inflated cuff pressure ranging from 30 to $50 \mathrm{mmHg}$ above the systolic blood pressure or from 200 to $250 \mathrm{mmHg}$ to occlude the brachial artery for 4.5-5 min (Table 1). The images of post-deflation diameter were continuously recorded within a time-window that logged from the last $30 \mathrm{~s}$ of occlusion through $180 \mathrm{~s}$ of hyperemia. Of the included studies, four reported the approaches for randomization, and three utilized perprotocol analyses (see Additional file 1: Table S2). The dropout rates of included studies were low in general except two around $20 \%$. 


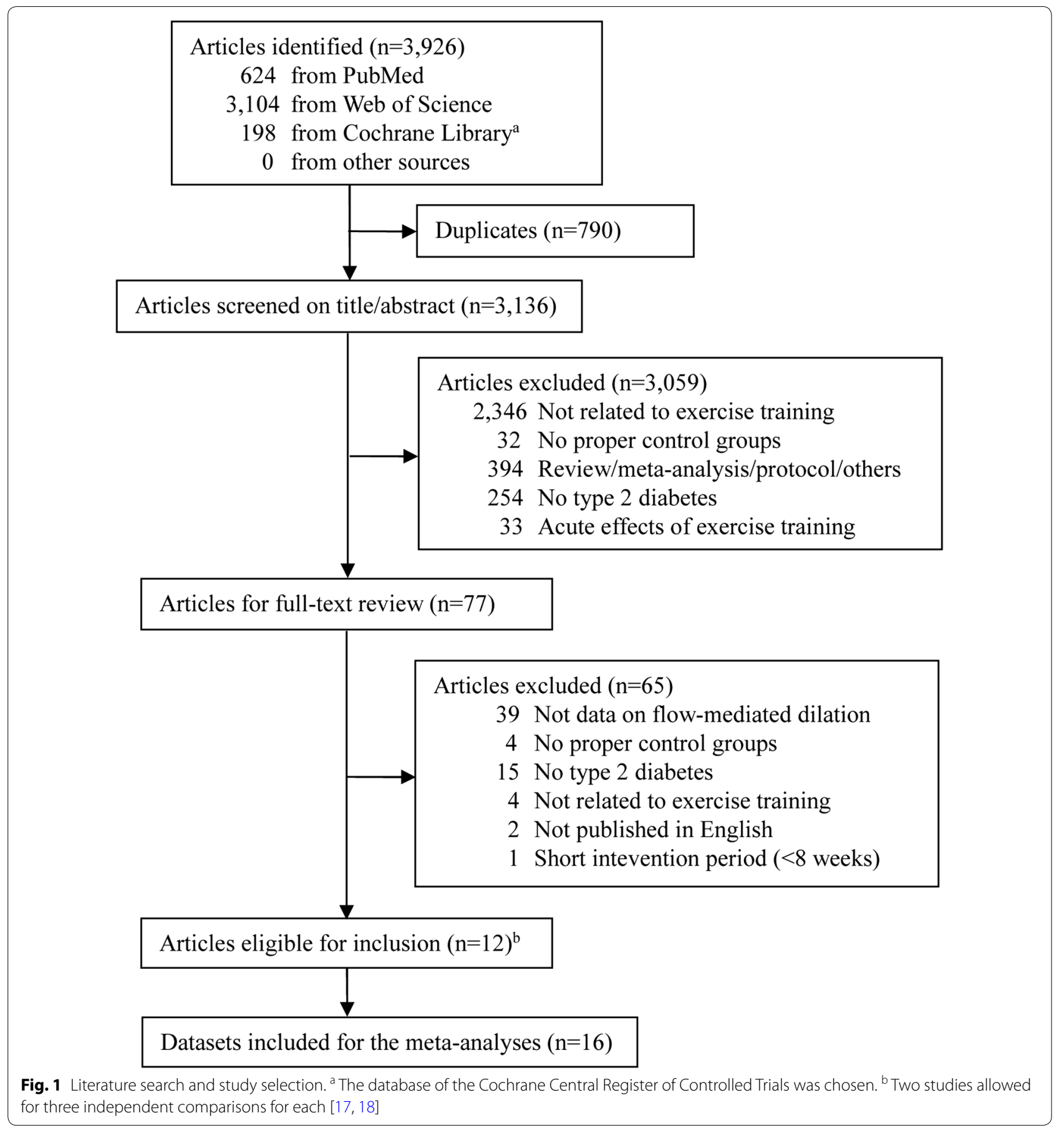

\section{Exercise training and endothelial function in type $\mathbf{2}$ \\ diabetes \\ Compared with non-exercise controls}

Ten RCTs from eight studies enrolling 377 patients with type 2 diabetes were included [16-23]. Metaanalysis showed that exercise training led to an overall improvement in FMD by $1.77 \%$ (95\% CI $0.94-2.59 \%$ ), with no evidence of heterogeneity $\left(I^{2}=35.3 \%\right.$; Fig. $\left.2 \mathrm{a}\right)$.
When taking exercise types into consideration, results showed that the FMD was increased by $1.21 \%(95 \%$ CI $0.23-2.19 \%, I^{2}=13.8 \%$ ) for aerobic exercise (five RCTs with 168 patients), $2.49 \%$ (95\% CI $1.17-3.81 \%$, $\left.I^{2}=35.3 \%\right)$ for combined aerobic and resistance exercise (four RCTs with 190 patients), and 1.60\% (95\% CI -0.52 to $3.72 \%$ ) for resistance exercise (one RCT with 19 patients). 


\section{Table 1 Characteristics of studies included in this meta-analysis}

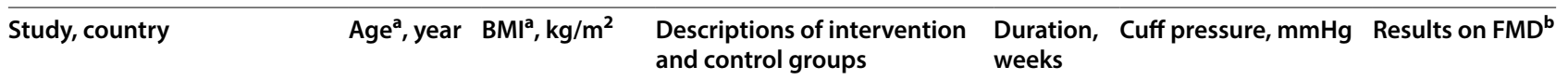

A. Exercise training and endothelial function in type 2 diabetes

(i) Aerobic exercise

\begin{tabular}{|c|c|c|c|c|c|c|}
\hline \multirow[t]{2}{*}{ Choi et al. 2012 [16]; Korea } & 53.8 & 26.8 in average & $\begin{array}{l}\text { Intervention: } 60 \mathrm{~min} / \mathrm{session} \\
\text { of walking at moderate } \\
\text { intensity, } 5 \text { times/week }\end{array}$ & 12 & $250 \mathrm{mmHg}$ & No change \\
\hline & 55.0 & 26.8 in average & $\begin{array}{l}\text { Control: maintained usual } \\
\text { activities and were required } \\
\text { not to exercise }\end{array}$ & & & \\
\hline \multirow[t]{2}{*}{ Kwon et al. [17]; Koreac } & 55.5 & 26.7 & $\begin{array}{l}\text { Intervention: } 60 \text { min/session } \\
\text { of walking at moderate } \\
\text { intensity, } 5 \text { times/week }\end{array}$ & 12 & $250 \mathrm{mmHg}$ & Increase \\
\hline & 58.9 & 27 & $\begin{array}{l}\text { Control: maintained usual } \\
\text { activities and were required } \\
\text { not to exercise }\end{array}$ & & & \\
\hline \multirow[t]{2}{*}{$\begin{array}{l}\text { Mitranun et al. [18]; } \\
\text { Thailand }^{c}\end{array}$} & 61.2 & 29.6 & $\begin{array}{l}\text { Intervention: } 20-30 \text { min/ses- } \\
\text { sion of walking or running } \\
\text { consisted of } 4-6 \text { intervals } \\
\text { of } 1 \text { min exercise at } 80-85 \% \\
\mathrm{VO}_{2 \text { peak }} \text { with a } 4 \text { min exercise } \\
\text { at } 50-60 \% \mathrm{VO}_{2 \text { peak, }} 3 \text { times/ } \\
\text { week }\end{array}$ & 12 & 50 mmHg over SBP & Increase \\
\hline & 60.9 & 29.7 & $\begin{array}{l}\text { Control: maintained sedentary } \\
\text { as previous }\end{array}$ & & & \\
\hline \multirow[t]{2}{*}{$\begin{array}{l}\text { Mitranun et al. [18]; } \\
\text { Thailand }\end{array}$} & 61.7 & 29.4 & $\begin{array}{l}\text { Intervention: } 20-30 \mathrm{~min} / \mathrm{ses}- \\
\text { sion of walking or running } \\
\text { at } 60-65 \% \mathrm{VO}_{2 \text { peak' }} 3 \text { times/ } \\
\text { week }\end{array}$ & 12 & 50 mmHg over SBP & Increase \\
\hline & 60.9 & 29.7 & $\begin{array}{l}\text { Control: maintained sedentary } \\
\text { as previous }\end{array}$ & & & \\
\hline \multirow[t]{2}{*}{$\begin{array}{l}\text { Wycherley et al. } 2008 \text { [19]; } \\
\text { Australia }\end{array}$} & 51.7 & 33.6 & $\begin{array}{l}\text { Intervention: } 25-60 \text { min/ses- } \\
\text { sion of walking or jogging } \\
\text { at intensity increasing from } \\
60 \text { to } 80 \% \mathrm{HR}_{\text {max }} 4-5 \text { times/ } \\
\text { week, plus a moderate } \\
\text { energy-restricted dietary } \\
\text { programme }\end{array}$ & 12 & $200 \mathrm{mmHg}$ & No change \\
\hline & 53.0 & 34.6 & $\begin{array}{l}\text { Control: a moderate energy- } \\
\text { restricted dietary program as } \\
\text { intervention }\end{array}$ & & & \\
\hline \multicolumn{7}{|c|}{ ii) Aerobic combined with resistance exercise } \\
\hline \multirow[t]{2}{*}{ Gibbs et al. 2012 [20]; USA } & 58 & 32.3 & $\begin{array}{l}\text { Intervention: } 45 \text { min of aerobic } \\
\text { exercise at } 60-90 \% \text { HR } \mathrm{R}_{\text {max }} \\
\text { along with } 7 \text { weight training } \\
\text { exercises with two sets of } \\
\text { 12-15 repetitions at } 50 \% \text { of } \\
\text { 1-repetition maximum for } \\
\text { each session, } 3 \text { times/week, } \\
\text { plus usual care }\end{array}$ & 26 & $>200 \mathrm{mmHg}$ & No change \\
\hline & 56 & 33.5 & Control: usual care & & & \\
\hline \multirow[t]{2}{*}{$\begin{array}{l}\text { Maiorana et al. } 2001 \text { [21]; } \\
\text { Australia }\end{array}$} & 52 & NS & $\begin{array}{l}\text { Intervention: } 60 \mathrm{~min} / \text { session } \\
\text { (15 exercises) of combined } \\
\text { aerobic exercise (riding/walk- } \\
\text { ing) at } 70-85 \% \mathrm{HR}_{\max } \text { and } \\
\text { resistance training at 55-65\% } \\
\text { MVC, with training intensity } \\
\text { and duration gradually } \\
\text { increased, } 3 \text { times/week, }\end{array}$ & 8 & $250 \mathrm{mmHg}$ & Increase \\
\hline & 52 & NS & $\begin{array}{l}\text { Control: were not required to } \\
\text { exercise }\end{array}$ & & & \\
\hline
\end{tabular}


Table 1 (continued)

\begin{tabular}{|c|c|c|c|c|c|c|}
\hline Study, country & Age $^{a}$, year & $\mathrm{BMI}^{\mathrm{a}}, \mathrm{kg} / \mathrm{m}^{2}$ & $\begin{array}{l}\text { Descriptions of intervention } \\
\text { and control groups }\end{array}$ & $\begin{array}{l}\text { Duration, } \\
\text { weeks }\end{array}$ & Cuff pressure, $\mathrm{mmHg}$ & Results on FMD \\
\hline \multirow[t]{2}{*}{$\begin{array}{l}\text { Naylor et al. } 2016 \text { [22]; } \\
\text { Australia }\end{array}$} & 17.3 & 36.1 & $\begin{array}{l}\text { Intervention: } 60 \mathrm{~min} / \text { session of } \\
\text { combined aerobic exercise } \\
\text { at } 65-85 \% \mathrm{HR}_{\max } \text { and resist- } \\
\text { ance training at } 55-70 \% \\
\text { MVC, with training volume } \\
\text { gradually increased, } 3 \text { times/ } \\
\text { week, plus standard care }\end{array}$ & 12 & $220 \mathrm{mmHg}$ & No change \\
\hline & 15.3 & 30.0 & Control: standard care & & & \\
\hline \multirow[t]{2}{*}{$\begin{array}{l}\text { Okada et al. } 2010 \text { [23]; } \\
\text { Japan }\end{array}$} & 61.9 & 25.7 & $\begin{array}{l}\text { Intervention: } 20 \text { min of aerobic } \\
\text { dancing, } 20 \text { min of bicycle } \\
\text { riding, and } 20 \text { min of resist- } \\
\text { ance training for each ses- } \\
\text { sion, 3-5 times/week, plus } \\
\text { usual care }\end{array}$ & 12 & $220 \mathrm{mmHg}$ & No change \\
\hline & 64.5 & 24.5 & Control: usual care & & & \\
\hline \multicolumn{7}{|l|}{ (iii) Resistance exercise } \\
\hline \multirow[t]{2}{*}{ Kwon et al. [17]; Koreac } & 56.3 & 27.4 & $\begin{array}{l}\text { Intervention: } 40 \text { min of } \\
\text { resistance bands exercise at } \\
\text { gradually increased intensi- } \\
\text { ties, three sets of 10-15 } \\
\text { exercises for each session, } 3 \\
\text { times/week }\end{array}$ & 12 & $250 \mathrm{mmHg}$ & No change \\
\hline & 58.9 & 27 & $\begin{array}{l}\text { Control: maintained usual } \\
\text { activities and were not } \\
\text { required to exercise }\end{array}$ & & & \\
\hline \multicolumn{7}{|c|}{ (iv) Interval versus continuous aerobic exercise } \\
\hline \multirow[t]{2}{*}{$\begin{array}{l}\text { Hollekim-Strand et al. } 2014 \\
\text { [24]; Norway }\end{array}$} & 58.6 & 30.2 & $\begin{array}{l}\text { Interval: } 25 \text { min/session of } \\
\text { walking or jogging consisted } \\
\text { of four intervals of } 4 \text { min } \\
\text { exercise at } 90-95 \% \mathrm{HR}_{\max } \\
\text { with a } 3 \text { min exercise at } 70 \% \\
\text { HR } R_{\text {max }} 3 \text { times/week }\end{array}$ & 12 & NS & Increase \\
\hline & 54.7 & 29.7 & $\begin{array}{l}\text { Continuous: } 210 \mathrm{~min} / \text { week } \\
\text { of home-based moderate } \\
\text { intensity exercise }\end{array}$ & & & \\
\hline \multirow[t]{2}{*}{$\begin{array}{l}\text { Mitranun et al. [18]; } \\
\text { Thailand }\end{array}$} & 61.2 & 29.6 & $\begin{array}{l}\text { Interval: } 20-30 \mathrm{~min} / \text { session of } \\
\text { walking or running consisted } \\
\text { of } 4-6 \text { intervals of } 1 \mathrm{~min} \\
\text { exercise at } 80-85 \% \mathrm{VO}_{2 \text { peak }} \\
\text { with a } 4 \text { min exercise at } \\
50-60 \% \mathrm{VO}_{2 \text { peak', }} \text { times/ } \\
\text { week }\end{array}$ & 12 & 50 mmHg over SBP & No change \\
\hline & 61.7 & 29.4 & $\begin{array}{l}\text { Continuous: } 20-30 \text { min/ses- } \\
\text { sion of walking or running } \\
\text { at } 60-65 \% \mathrm{VO}_{2 \text { peak, }} 3 \text { times/ } \\
\text { week }\end{array}$ & & & \\
\hline \multicolumn{7}{|c|}{ (v) Aerobic versus resistance exercise } \\
\hline \multirow[t]{2}{*}{ Kwon et al. [17]; Koreac } & 55.5 & 26.7 & $\begin{array}{l}\text { Aerobic: } 60 \mathrm{~min} / \mathrm{session} \text { of } \\
\text { walking at moderate inten- } \\
\text { sity, } 5 \text { times/week }\end{array}$ & 12 & $250 \mathrm{mmHg}$ & No change \\
\hline & 56.3 & 27.4 & $\begin{array}{l}\text { Resistance: } 40 \text { min of resist- } \\
\text { ance bands exercise at } \\
\text { gradually increased intensi- } \\
\text { ties, } 3 \text { sets of } 10-15 \text { exercises } \\
\text { for each session, } 3 \text { times/ } \\
\text { week }\end{array}$ & & & \\
\hline
\end{tabular}


Table 1 (continued)

\begin{tabular}{|c|c|c|c|c|c|c|}
\hline Study, country & Age $^{a}$, year & $\mathrm{BMI}^{\mathrm{a}}, \mathrm{kg} / \mathrm{m}^{2}$ & $\begin{array}{l}\text { Descriptions of intervention } \\
\text { and control groups }\end{array}$ & $\begin{array}{l}\text { Duration, } \\
\text { weeks }\end{array}$ & Cuff pressure, $\mathrm{mmHg}$ & Results on FMD \\
\hline \multicolumn{7}{|c|}{ B. Exercise training and endothelial function in type 2 diabetes versus non-diabetes } \\
\hline \multirow[t]{2}{*}{ Allen et al. [31]; USA } & 66 & 27 & $\begin{array}{l}\text { Diabetics: } 30-40 \text { min/session } \\
\text { of walking, with intensities } \\
\text { gradually increased from } \\
\text { the one set to the workload } \\
\text { resulting in claudication pain } \\
\text { during maximal treadmill } \\
\text { test, } 3 \text { times/week }\end{array}$ & 12 & $240 \mathrm{mmHg}$ & NA \\
\hline & 69 & 25 & $\begin{array}{l}\text { Non-diabetics: the same as } \\
\text { diabetics }\end{array}$ & & & \\
\hline \multirow[t]{2}{*}{ Madsen et al. [32]; Denmark } & 56 & 31.1 & $\begin{array}{l}\text { Diabetics: } 20 \text { min/session } \\
\text { of cycling consisted of } 10 \\
\text { intervals of } 1 \text { min exercise at } \\
65-69 \% \mathrm{HR}_{\max } \text { with a } 1 \text { min } \\
\text { active recovery exercise, } 3 \\
\text { times/week }\end{array}$ & 8 & $\geq 220 \mathrm{mmHg}$ & NA \\
\hline & 52 & 30.5 & $\begin{array}{l}\text { Non-diabetics: the same as } \\
\text { diabetics }\end{array}$ & & & \\
\hline \multirow[t]{2}{*}{$\begin{array}{l}\text { Schreuder et al. [33]; Neth- } \\
\text { erlands }\end{array}$} & 59 & 32.4 & $\begin{array}{l}\text { Diabetics: } 55 \text { min/session of a } \\
\text { circuit of resistance exercises } \\
\text { (six exercises, } 3 \text { series of } 12 \\
\text { repetitions for each exercise) } \\
\text { interspersed with aerobic } \\
\text { exercise (cycling/running, } \\
5 \text { min for each) at 70-75\% } \\
\text { HRR, with intensities gradu- } \\
\text { ally increased, } 3 \text { times/week }\end{array}$ & 8 & $220 \mathrm{mmHg}$ & NA \\
\hline & 58 & 26.9 & $\begin{array}{l}\text { Non-diabetics: the same as } \\
\text { diabetics }\end{array}$ & & & \\
\hline \multicolumn{7}{|c|}{$\begin{array}{l}B M I \text { body mass index, } F M D \text { flow-mediated dilation, } V O_{2 p e a k} \text { peak oxygen uptake, } H R_{\text {max }} \text { maximum heart rate, } M V C \text { maximal voluntary contraction, } H R R \text { heart rate } \\
\text { reserve, } N A \text { not applicable }\end{array}$} \\
\hline \multicolumn{7}{|c|}{ a They represented the baseline mean data for each group } \\
\hline \multicolumn{7}{|c|}{ b It represented the results on the comparisons between intervention and control groups } \\
\hline \multicolumn{7}{|c|}{ c Both studies allowed for three independent comparisons for each $[17,18]$} \\
\hline
\end{tabular}

Univariate meta-regression analyses suggested that changes in FMD related to exercise training or specifically aerobic or combined exercise was not significantly associated with any of the baseline values or changes scores of BMI, blood pressure, glycemic control, or peak oxygen consumption (all $P>0.05$; Table 2). Sensitivity analyses indicated that the improvements in FMD associated with exercise training or specifically aerobic or combined exercise still remained significant and were not significantly altered after excluding studies having non-exercise interventions, reporting substantial changes in medication use, or utilizing the per-protocol analyses (Table 3). No evidence of publication bias was observed for FMD results associated with exercise training or specifically aerobic or combined exercise (All $P>0.80$ for both Begg's and Egger's tests).

\section{Compared across exercise types}

Three RCTs made comparisons between the effects of different exercise types on FMD in patients with type 2 diabetes $[17,18,24]$. Results showed that neither highintensity interval aerobic exercise significantly improved FMD over moderate-intensity continuous exercise (two RCTs, WMD $4.79 \%$, 95\% CI -2.90 to $12.49 \%$; Fig. $2 b$ ), nor aerobic versus resistance exercise (one RCT, WMD $0.80 \%, 95 \% \mathrm{CI}-1.09$ to $2.69 \%)$.

\section{Exercise training and endothelial function in type 2 diabetics vs non-diabetics}

Three controlled studies with 36 type 2 diabetics and 37 non-diabetics were included in this meta-analysis [3133]. In these studies, increases in FMD were observed among type 2 diabetics (from 0.5 to $0.82 \%$ ) and non-diabetics (from 1.46 to $2.1 \%$ ) following 8-12 weeks of exercise training. Pooled results indicated that the magnitude of the improvements in FMD was smaller in type 2 diabetics than non-diabetics after exercise training (WMD $-0.72 \%, 95 \%$ CI -1.36 to $-0.08 \%$; $I^{2}<1 \%$; Fig. 2 c) or specifically, after aerobic exercise (two studies, WMD $-0.65 \%, 95 \%$ CI -1.31 to $\left.0.01 \% ; I^{2}=36.7 \%\right)$. 


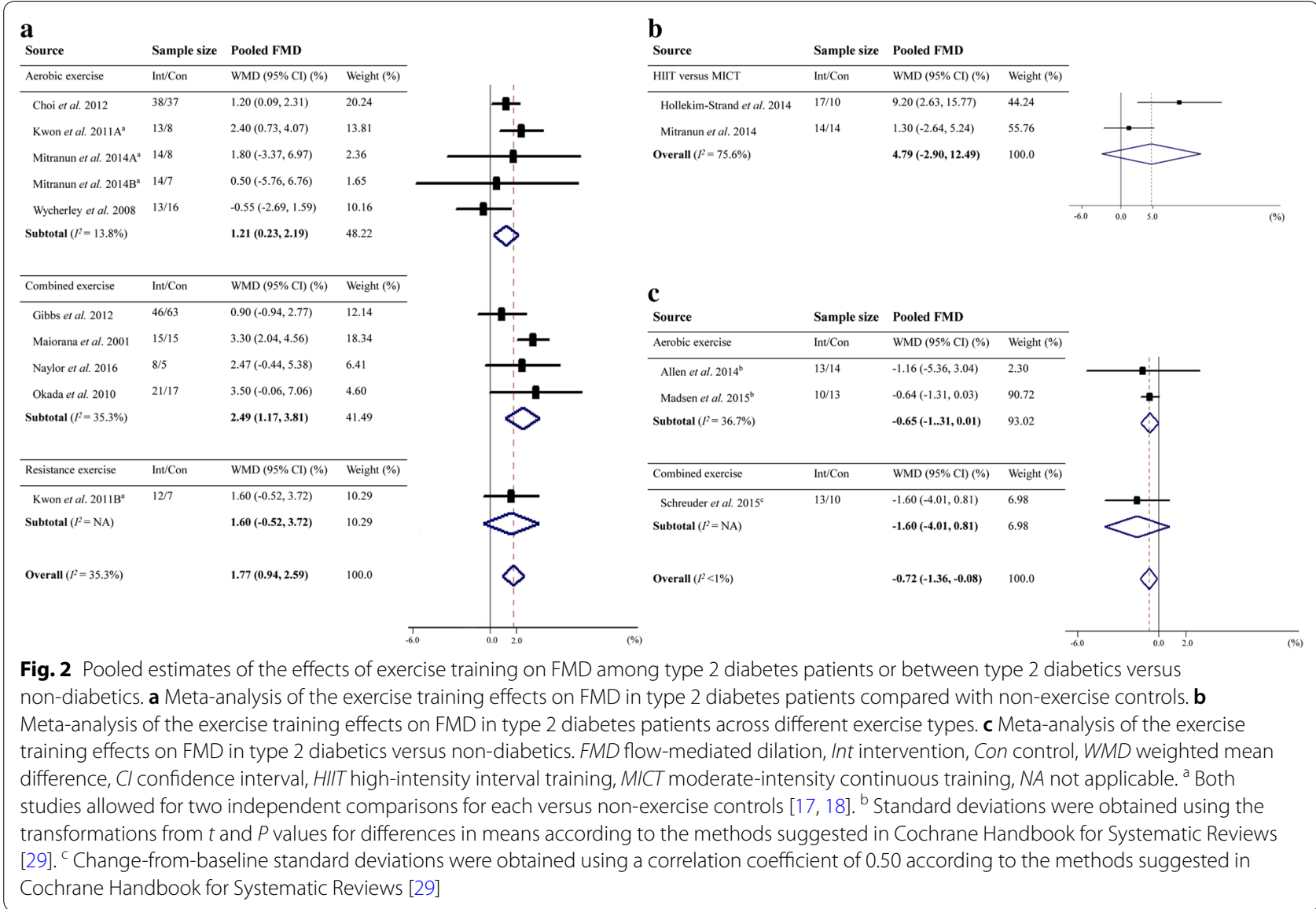

\section{Discussion}

\section{Summary of the main findings}

Our meta-analysis revealed that exercise training, in particular aerobic and combined aerobic and resistance exercise, significantly improved endothelial function in patients with type 2 diabetes, as indicated by increased FMD; and this manner seemed to be independent of changes in traditional cardiometabolic markers including BMI, blood pressure, glycemic control, or cardiorespiratory fitness in relation to exercise training. However, our meta-analysis did not provide adequate evidence that high-intensity interval aerobic exercise was superior to moderate-intensity continuous aerobic exercise in improving endothelial function. Noteworthy, the increases in FMD in response to exercise training in type 2 diabetics were lower than that in non-diabetics, indicating that the presence of diabetes may weaken the exercise training effects on endothelial function.

\section{Interpretations}

Our study showed that exercise training, a non-pharmacological therapy, led to an overall improvement in FMD by $1.77 \%$. This is of clinical importance for patients with type 2 diabetes, since on the one hand, every $1 \%$ increase in FMD was correlated with an estimated 13\% risk reduction of cardiovascular events based on the report from van Sloten and colleagues [35]; and on the other hand, such an increase in FMD is even larger than or comparable to those from pharmacological interventions like statin therapy [36] or phosphodiesterase inhibitors use [37], which result in an improvement in FMD by $0.94 \%$ (95\% CI $0.38-1.5 \%$ ) and $2.19 \%$ (95\% CI $0.48-3.90 \%$ ), respectively. Although not fully understood, it is speculated that the observed beneficial effects of exercise training on endothelial function might be underlined by the following mechanisms. Firstly, exercise training causes an increase in blood flow, which augments shear stresses on the endothelium, leading to increased nitric oxide synthesis and bioavailability [1]. Secondly, exercise training reduces oxidative stress and the expression of pro-inflammatory molecules [38], both of which are considered initiating factors for endothelial dysfunction. Thirdly, exercise training may help to restore the function of endothelial progenitor cells, promoting endothelial repair and facilitating vascular angiogenesis subsequently [39]. 
Table 2 Meta-regression analyses on FMD in patients with type 2 diabetes

\begin{tabular}{|c|c|c|c|c|c|c|c|c|c|}
\hline \multirow[t]{2}{*}{ Variables } & \multicolumn{3}{|c|}{ All exercise } & \multicolumn{3}{|c|}{ Aerobic exercise } & \multicolumn{3}{|c|}{ Combined exercise } \\
\hline & $\mathbf{N}$ & $\beta$ & $P$ & $\mathrm{~N}$ & $\beta$ & $P$ & $\mathrm{~N}$ & $\beta$ & $P$ \\
\hline Age (log-transformed) ${ }^{\mathrm{a}}$ & 10 & -0.53 & 0.72 & 5 & 20.1 & 0.17 & 4 & -0.06 & 0.97 \\
\hline Disease duration ${ }^{\mathrm{a}}$ & 6 & -0.03 & 0.82 & 3 & -0.08 & 0.69 & 2 & NA & NA \\
\hline Training duration & 10 & -0.10 & 0.26 & 5 & NA & NA & 4 & -0.13 & 0.17 \\
\hline Proportion of males ${ }^{a}$ & 10 & 0.01 & 0.50 & 5 & -0.04 & 0.20 & 4 & 0.06 & 0.28 \\
\hline \multicolumn{10}{|l|}{ Baseline data $a^{a}$} \\
\hline FMD at baseline & 9 & 0.43 & 0.23 & 5 & 1.33 & 0.29 & 3 & 1.16 & 0.48 \\
\hline Body mass index & 10 & -0.16 & 0.34 & 5 & -0.30 & 0.19 & 4 & -0.32 & 0.34 \\
\hline Systolic blood pressure & 6 & 0.03 & 0.70 & 4 & -0.10 & 0.34 & 2 & NA & NA \\
\hline Diastolic blood pressure & 6 & 0.01 & 0.95 & 4 & 0.41 & 0.30 & 2 & NA & NA \\
\hline Mean arterial pressure & 7 & 0.23 & 0.05 & 4 & -0.19 & 0.76 & 3 & 0.20 & 0.28 \\
\hline Fasting blood glucose & 6 & 0.17 & 0.73 & 4 & -0.71 & 0.29 & 2 & NA & NA \\
\hline Hemoglobin A1c & 10 & 1.11 & 0.09 & 5 & -1.97 & 0.44 & 4 & 1.21 & 0.17 \\
\hline Peak oxygen consumption & 8 & -0.01 & 0.95 & 3 & -3.27 & 0.61 & 4 & -0.03 & 0.95 \\
\hline \multicolumn{10}{|c|}{ Change scores post-exercise intervention ${ }^{b}$} \\
\hline Body mass index & 6 & -2.10 & 0.55 & 3 & -4.64 & 0.57 & 3 & 3.60 & 0.59 \\
\hline Systolic blood pressure & 6 & -0.16 & 0.30 & 4 & -0.20 & 0.28 & 2 & NA & NA \\
\hline Diastolic blood pressure & 6 & -0.10 & 0.55 & 4 & -0.22 & 0.35 & 2 & NA & NA \\
\hline Fasting blood glucose & 5 & 1.44 & 0.62 & 4 & -4.66 & 0.34 & 1 & NA & NA \\
\hline Hemoglobin A1c & 9 & -2.52 & 0.24 & 5 & -5.02 & 0.12 & 3 & 1.96 & 0.73 \\
\hline Peak oxygen consumption & 6 & -0.38 & 0.74 & 3 & 1.14 & 0.55 & 3 & -1.40 & 0.52 \\
\hline
\end{tabular}

FMD flow-mediated dilation, NA not applicable

a They were the baseline mean values of intervention and control groups

b They were the average change cores from baseline between intervention and control groups except the study by Maiorana and colleague [21]

Table 3 Sensitivity analyses on FMD in patients with type 2 diabetes

\begin{tabular}{|c|c|c|c|c|c|c|c|c|c|}
\hline \multirow[t]{2}{*}{ Study characteristics } & \multicolumn{3}{|c|}{ All exercise } & \multicolumn{3}{|c|}{ Aerobic exercise } & \multicolumn{3}{|c|}{ Combined exercise } \\
\hline & $\mathbf{N}$ & WMD (\%) & $95 \% \mathrm{Cl}$ & $\mathbf{N}$ & WMD (\%) & $95 \% \mathrm{Cl}$ & $\mathrm{N}$ & WMD (\%) & $95 \% \mathrm{Cl}$ \\
\hline Exercise training as the sole intervention & 8 & 2.00 & $1.23-2.77 \%$ & 4 & 1.64 & $0.79-2.49 \%$ & 3 & 2.47 & $0.70-4.23 \%$ \\
\hline No or minor changes in medication use & 8 & 2.16 & $1.48-2.85 \%$ & 4 & 1.64 & $0.79-2.49 \%$ & 3 & 3.20 & $2.10-4.30 \%$ \\
\hline Using intention-to-treat analysis & 8 & 2.39 & $1.64-3.15 \%$ & 3 & 2.27 & $0.94-3.61 \%$ & 4 & 2.49 & $1.17-3.81 \%$ \\
\hline
\end{tabular}

FMD flow-mediated dilation, WMD weighted mean difference, $\mathrm{Cl}$ confidence interval

Partly in agreement with our finding, the prior metaanalysis by Montero and colleagues as well as the review paper by Miele and colleagues had also observed the beneficial effects of exercise training on endothelial function assessed by FMD in patients with type 2 diabetes $[13,26]$. However, our study, which included more RCTs and introduced subgroup and meta-regression analyses, extended their findings by providing in-depth analyses of the training effects from the specific exercise type on FMD and exploring the potential moderators. In our study despite a non-significant increase in FMD after resistance exercise, both aerobic and combined exercise were effective in improving FMD, which corresponds well with the results from the meta-analysis conducted in a heterogeneous adult population [40]. Yet inconsistent with our finding, Way and colleagues argued that aerobic exercise may not be able to improve FMD in patients with type 2 diabetes [41], which might be due to their limited number of studies included.

In addition, the largest increase in FMD observed in combined exercise suggests that this mixed form might be superior to aerobic or resistance exercise in improving endothelial function based on our subgroup analyses across exercise types with indirect comparisons. However, it is noteworthy that they may not control for energy expenditure or training duration in every section, 
and that there was only a single study with a small sample size that explored the influence of resistance exercise on endothelial function [17], which might affect the outcomes of interest (e.g., may underestimate the effects of resistance exercise). Future studies are in need to determine which exercise type might be the best one in increasing FMD using head-to-head designs with the energy expenditure- and/or training time-matched for each section across different exercise types.

In recent years Ramos and colleagues reported that high-intensity interval aerobic exercise, which acts in a time-saving manner $[42,43]$, produces a greater positive influence on endothelial function versus moderate-intensity continuous aerobic exercise in a mixed adult population [44]. However, our meta-analysis in patients with type 2 diabetes did not provide adequate evidence in support of this notion, which might be largely attributable to the differences in the target populations as well as the small number of studies included. Moreover, Ramos and colleagues pointed out that the improvement in endothelial function associated with high-intensity interval aerobic exercise over moderate-intensity continuous exercise might be owing to its superiority in increasing cardiorespiratory fitness, improving glycemic control, and lowering blood pressure, suggesting a potential positive linkage between endothelial function and cardiometabolic markers [44]. Yet our meta-regression analyses, based on the averages of participant characteristics for each study did not support such an assumption, which could be also evidenced by the findings from the individual study by Gibbs and colleagues [20] and the cross-sectional observation [45]. It seems likely that the benefits of exercise training on endothelial function are independent of improvements in cardiometabolic health among patients with type 2 diabetes, which, albeit, still requires further investigations using the individual participant data.

In addition to suggesting a positive influence of exercise training on endothelial function in patients with type 2 diabetes, our study showed that the improvement in endothelial function in response to chronic exercise training was weakened in patients with type 2 diabetes compared with those without. Although the exact mechanism is not well understood, it is speculated that the presence of diabetes may compromise the ability of the endothelium to endogenously increase vascular nitric oxide bioavailability following exercise training [31], possibly because of the persistent hyperglycemia and the increased levels of circulating advanced glycation end products or reactive oxygen species [46, 47]. Moreover, the blunted potential of exercise to stimulate and to mobilize endothelial progenitor cells observed in diabetic patients compared with non-diabetic controls might also contribute to the weakened improvement in endothelial function in response to exercise among type 2 diabetes [46]. These may indicate that more interventions apart from promoting physical exercise might be needed for patients with type 2 diabetes to obtain comparable health benefits like healthy or non-diabetic controls.

\section{Limitations}

Despite a comprehensive exploration of the exercise training effects on endothelial function among patients with type 2 diabetes, this meta-analysis has some limitations. Firstly, some studies reported changes in medication use in the intervention period or used cointerventions like dietary programs [48], which may influence the endothelial function and contributed to heterogeneity. However, our sensitivity analyses indicated that they are unlikely to have important impacts on the main findings. Secondly, most of the included studies implemented exercise interventions within 12 weeks, which largely represents a relatively short-term effect on endothelial function, although our meta-regression analysis suggested that intervention periods were not likely to affect the changes in endothelial function associated with exercise training. More studies are therefore warranted to explore the long-term (e.g., over 6 months) effects of exercise training on endothelial function, just as suggested by Lenasi and colleagues [46]. Thirdly, some variances existed in the measurement methods for FMD. However, these methods were well defined in general. Although it is reported that the measurement of peak dilation at $60 \mathrm{~s}$ after cuff release may result in an underestimation of true FMD by up to $40 \%$ [49], this factor seems to have had a minor influence on our outcomes on FMD since all studies except the one by Hollekim-Strand and colleagues [24] had already adopted a continuous measurement of post-deflation diameter within the time-window as aforementioned. Finally, our study did not search for unpublished studies and had a language restriction, which may cause some selection bias.

\section{Conclusion}

In summary, this meta-analysis indicates that exercise training, especially aerobic or combined aerobic and resistance exercise, improves endothelial function in patients with type 2 diabetes. Such an improvement is likely to be independent of changes in traditional cardiometabolic markers associated with exercise training, but appears to be weakened compared with a non-diabetes state. Notably, despite a larger effect that was seen with combined exercise in improving endothelial function compared with aerobic or resistance exercise alone, studies did not have specifications on the controls for energy expenditure or training time for every section. Future studies with longer intervention durations are required 
to sort out the optimal exercise type to improve pathological conditions of endothelial dysfunction in patients with type 2 diabetes using head-to-head designs with the energy expenditure- and/or training time-matched for each section across different exercise types.

\section{Additional file}

Additional file 1: Table S1. Search strategies. Table S2. Quality

assessment.

\section{Abbreviations}

RCTs: randomized controlled trials; FMD: flow-mediated dilation; PRISMA: Preferred Reporting Items for Systematic Reviews and Meta-Analyses; BMI: body mass index; Cls: confidence intervals; WMD: weighted mean difference.

\section{Authors' contributions}

SQ conducted the study, collected the data, analysed the data, and wrote the manuscript. XC collected the data and contributed to the introduction. $M Z$ and JS contributed to the introduction, reviewed/edited the manuscript. $\mathrm{ZS}$, and US designed the study, contributed to the discussion, and edited the manuscript. All authors read and approved the final manuscript.

\section{Author details}

${ }^{1}$ Department of Endocrinology, Zhongda Hospital, Institute of Diabetes, School of Medicine, Southeast University, Nanjing, People's Republic of China.

${ }^{2}$ Division of Sports and Rehabilitation Medicine, Ulm University Medical Center, Ulm, Germany.

\section{Acknowledgements}

Not applicable.

\section{Competing interests}

The authors declare that they have no competing interests.

\section{Availability of data and materials}

All data generated or analyzed during this study are included in this published article and its Additional information files.

\section{Consent for publication}

Not applicable.

Ethics of approval and consent to participate

Not applicable.

\section{Funding}

Not applicable.

\section{Publisher's Note}

Springer Nature remains neutral with regard to jurisdictional claims in published maps and institutional affiliations.

Received: 7 March 2018 Accepted: 25 April 2018

Published online: 02 May 2018

\section{References}

1. Di Francescomarino S, Sciartilli A, Di Valerio V, Di Baldassarre A, Gallina S. The effect of physical exercise on endothelial function. Sports Med. 2009;39(10):797-812.

2. Widlansky ME, Gokce N, Keaney JF Jr, Vita JA. The clinical implications of endothelial dysfunction. J Am Coll Cardiol. 2003;42(7):1149-60.

3. Avogaro A, Albiero M, Menegazzo L, de Kreutzenberg S, Fadini GP. Endothelial dysfunction in diabetes: the role of reparatory mechanisms. Diabetes Care. 2011;34(Suppl 2):S285-90.
4. Suwaidi JA, Hamasaki S, Higano ST, Nishimura RA, Holmes DR Jr, Lerman A. Long-term follow-up of patients with mild coronary artery disease and endothelial dysfunction. Circulation. 2000;101(9):948-54.

5. Fetterman JL, Holbrook M, Westbrook DG, Brown JA, Feeley KP, BretonRomero R, Linder EA, Berk BD, Weisbrod RM, Widlansky ME, Gokce N, Ballinger SW, Hamburg NM. Mitochondrial DNA damage and vascular function in patients with diabetes mellitus and atherosclerotic cardiovascular disease. Cardiovasc Diabetol. 2016;15:53.

6. Henry RM, Ferreira I, Kostense PJ, Dekker JM, Nijpels G, Heine RJ, Kamp O, Bouter LM, Stehouwer CD. Type 2 diabetes is associated with impaired endothelium-dependent, flow-mediated dilation, but impaired glucose metabolism is not; The Hoorn Study. Atherosclerosis. 2004;174(1):49-56.

7. Casanova F, Adingupu DD, Adams F, Gooding KM, Looker HC, Aizawa K, Dove F, Elyas S, Belch JJF, Gates PE, Littleford RC, Gilchrist M, Colhoun HM, Shore AC, Khan F, Strain WD. The impact of cardiovascular co-morbidities and duration of diabetes on the association between microvascular function and glycaemic control. Cardiovasc Diabetol. 2017;16(1):114.

8. Meigs JB, Hu FB, Rifai N, Manson JE. Biomarkers of endothelial dysfunction and risk of type 2 diabetes mellitus. JAMA. 2004;291(16):1978-86.

9. Shi Y, Vanhoutte PM. Macro- and microvascular endothelial dysfunction in diabetes. J Diabetes. 2017;9(5):434-49.

10. Qiu S, Cai X, Schumann U, Velders M, Sun Z, Steinacker JM. Impact of walking on glycemic control and other cardiovascular risk factors in type 2 diabetes: a meta-analysis. PLoS ONE. 2014;9(10):e109767.

11. Grace A, Chan E, Giallauria F, Graham PL, Smart NA. Clinical outcomes and glycaemic responses to different aerobic exercise training intensities in type II diabetes: a systematic review and meta-analysis. Cardiovasc Diabetol. 2017;16(1):37.

12. Byrkjeland R, Stensaeth KH, Anderssen S, Njerve IU, Arnesen H, Seljeflot I, Solheim S. Effects of exercise training on carotid intima-media thickness in patients with type 2 diabetes and coronary artery disease. Influence of carotid plaques. Cardiovasc Diabetol. 2016;15:13.

13. Miele EM, Headley SAE. The effects of chronic aerobic exercise on cardiovascular risk factors in persons with diabetes mellitus. Curr Diab Rep. 2017;17(10):97.

14. Lew JK, Pearson JT, Schwenke DO, Katare R. Exercise mediated protection of diabetic heart through modulation of microRNA mediated molecular pathways. Cardiovasc Diabetol. 2017;16(1):10.

15. Avogaro A, de Kreutzenberg SV, Fadini G. Endothelial dysfunction: causes and consequences in patients with diabetes mellitus. Diabetes Res Clin Pract. 2008;82(Suppl 2):S94-101.

16. Choi KM, Han KA, Ahn HJ, Hwang SY, Hong HC, Choi HY, Yang SJ, Yoo HJ, Baik SH, Choi DS, Min KW. Effects of exercise on sRAGE levels and cardiometabolic risk factors in patients with type 2 diabetes: a randomized controlled trial. J Clin Endocrinol Metab. 2012;97(10):3751-8.

17. Kwon HR, Min KW, Ahn HJ, Seok HG, Lee JH, Park GS, Han KA. Effects of aerobic exercise vs. resistance training on endothelial function in women with type 2 diabetes mellitus. Diabetes Metab J. 2011;35(4):364-73.

18. Mitranun W, Deerochanawong C, Tanaka H, Suksom D. Continuous vs interval training on glycemic control and macro and microvascular reactivity in type 2 diabetic patients. Scand J Med Sci Sports. 2014;24(2):E69-76.

19. Wycherley TP, Brinkworth GD, Noakes M, Buckley JD, Clifton PM. Effect of caloric restriction with and without exercise training on oxidative stress and endothelial function in obese subjects with type 2 diabetes. Diabetes Obes Metab. 2008;10(11):1062-73.

20. Gibbs BB, Dobrosielski DA, Bonekamp S, Stewart KJ, Clark JM. A randomized trial of exercise for blood pressure reduction in type 2 diabetes: effect on flow-mediated dilation and circulating biomarkers of endothelial function. Atherosclerosis. 2012;224(2):446-53.

21. Maiorana A, O'Driscoll G, Cheetham C, Dembo L, Stanton K, Goodman C, Taylor R, Green D. The effect of combined aerobic and resistance exercise training on vascular function in type 2 diabetes. J Am Coll Cardiol. 2001;38(3):860-6

22. Naylor LH, Davis EA, Kalic RJ, Paramalingam N, Abraham MB, Jones TW, Green DJ. Exercise training improves vascular function in adolescents with type 2 diabetes. Physiol Rep. 2016;4(4). pii:e12713. https://doi. org/10.14814/phy2.12713.

23. Okada S, Hiuge A, Makino H, Nagumo A, Takaki H, Konishi H, Goto Y, Yoshimasa Y, Miyamoto Y. Effect of exercise intervention on endothelial 
function and incidence of cardiovascular disease in patients with type 2 diabetes. J Atheroscler Thromb. 2010;17(8):828-33.

24. Hollekim-Strand SM, Bjorgaas MR, Albrektsen G, Tjonna AE, Wisloff U, Ingul CB. High-intensity interval exercise effectively improves cardiac function in patients with type 2 diabetes mellitus and diastolic dysfunction a randomized controlled trial. J Am Coll Cardiol. 2014;64(16):1758-60.

25. Corretti MC, Anderson TJ, Benjamin EJ, Celermajer D, Charbonneau F, Creager MA, Deanfield J, Drexler H, Gerhard-Herman M, Herrington D, Vallance P. Vita J, Vogel R, International Brachial Artery Reactivity Task F. Guidelines for the ultrasound assessment of endothelial-dependent flowmediated vasodilation of the brachial artery: a report of the International Brachial Artery Reactivity Task Force. J Am Coll Cardiol. 2002;39(2):257-65.

26. Montero D, Walther G, Benamo E, Perez-Martin A, Vinet A. Effects of exercise training on arterial function in type 2 diabetes mellitus: a systematic review and meta-analysis. Sports Med. 2013;43(11):1191-9.

27. Moher D, Liberati A, Tetzlaff J, Altman DG, Group P. Preferred reporting items for systematic reviews and meta-analyses: the PRISMA statement. J Clin Epidemiol. 2009;62(10):1006-12.

28. Qiu S, Cai X, Sun Z, Zugel M, Steinacker JM, Schumann U. Aerobic interval training and cardiometabolic health in patients with type 2 diabetes: a meta-analysis. Front Physiol. 2017;8:957.

29. Higgins JPT, Green S, Cochrane Collaboration. Cochrane handbook for systematic reviews of interventions. Chichester: Wiley-Blackwell; 2008.

30. Cai X, Qiu S, Li L, Zugel M, Steinacker JM, Schumann U. Circulating irisin in patients with polycystic ovary syndrome: a meta-analysis. Reprod Biomed Online. 2018;36(2):172-80.

31. Allen JD, Stabler T, Kenjale AA, Ham KL, Robbins JL, Duscha BD, Kraus WE, Annex BH. Diabetes status differentiates endothelial function and plasma nitrite response to exercise stress in peripheral arterial disease following supervised training. J Diabetes Complications. 2014;28(2):219-25.

32. Madsen SM, Thorup AC, Overgaard K, Bjerre M, Jeppesen PB. Functional and structural vascular adaptations following 8 weeks of low volume high intensity interval training in lower leg of type 2 diabetes patients and individuals at high risk of metabolic syndrome. Arch Physiol Biochem. 2015;121(5):178-86.

33. Schreuder TH, Green DJ, Nyakayiru J, Hopman MT, Thijssen DH. Timecourse of vascular adaptations during 8 weeks of exercise training in subjects with type 2 diabetes and middle-aged controls. Eur J Appl Physiol. 2015;115(1):187-96.

34. Norton K, Norton L, Sadgrove D. Position statement on physical activity and exercise intensity terminology. J Sci Med Sport. 2010;13(5):496-502.

35. van Sloten TT, Henry RM, Dekker JM, Nijpels G, Unger T, Schram MT, Stehouwer CD. Endothelial dysfunction plays a key role in increasing cardiovascular risk in type 2 diabetes: the Hoorn study. Hypertension. 2014;64(6):1299-305.

36. Zhang L, Gong D, Li S, Zhou X. Meta-analysis of the effects of statin therapy on endothelial function in patients with diabetes mellitus. Atherosclerosis. 2012;223(1):78-85.
37. Santi D, Giannetta E, Isidori AM, Vitale C, Aversa A, Simoni M. Therapy of endocrine disease: effects of chronic use of phosphodiesterase inhibitors on endothelial markers in type 2 diabetes mellitus: a meta-analysis. Eur J Endocrinol. 2015;172(3):R103-14.

38. Teixeira-Lemos E, Nunes S, Teixeira F, Reis F. Regular physical exercise training assists in preventing type 2 diabetes development: focus on its antioxidant and anti-inflammatory properties. Cardiovasc Diabetol. 2011;10:12

39. Koutroumpi M, Dimopoulos S, Psarra K, Kyprianou T, Nanas S. Circulating endothelial and progenitor cells: evidence from acute and long-term exercise effects. World J Cardiol. 2012;4(12):312-26.

40. Ashor AW, Lara J, Siervo M, Celis-Morales C, Oggioni C, Jakovljevic DG, Mathers JC. Exercise modalities and endothelial function: a systematic review and dose-response meta-analysis of randomized controlled trials. Sports Med. 2015;45(2):279-96.

41. Way KL, Keating SE, Baker MK, Chuter VH, Johnson NA. The effect of exercise on vascular function and stiffness in type 2 diabetes: a systematic review and meta-analysis. Curr Diabetes Rev. 2016;12(4):369-83.

42. Garcia-Hermoso A, Cerrillo-Urbina AJ, Herrera-Valenzuela T, Cristi-Montero C, Saavedra JM, Martinez-Vizcaino V. Is high-intensity interval training more effective on improving cardiometabolic risk and aerobic capacity than other forms of exercise in overweight and obese youth? A metaanalysis. Obes Rev. 2016;17(6):531-40.

43. Francois ME, Durrer C, Pistawka KJ, Halperin FA, Chang C, Little JP. Combined interval training and post-exercise nutrition in type 2 diabetes: a randomized control trial. Front Physiol. 2017;8:528.

44. Ramos JS, Dalleck LC, Tjonna AE, Beetham KS, Coombes JS. The impact of high-intensity interval training versus moderate-intensity continuous training on vascular function: a systematic review and meta-analysis. Sports Med. 2015;45(5):679-92.

45. Sonmez A, Yilmaz MI, Saglam M, Kilic S, Eyileten T, Uckaya G, Caglar K, Oguz Y, Vural A, Yenicesu M, Kutlu M, Kinalp C, Zoccali C. The relationship between hemoglobin levels and endothelial functions in diabetes mellitus. Clin J Am Soc Nephrol. 2010;5(1):45-50.

46. Lenasi H, Klonizakis M. Assessing the evidence: exploring the effects of exercise on diabetic microcirculation. Clin Hemorheol Microcirc. 2016;64(4):663-78.

47. Ren X, Ren L, Wei Q, Shao H, Chen L, Liu N. Advanced glycation end-products decreases expression of endothelial nitric oxide synthase through oxidative stress in human coronary artery endothelial cells. Cardiovasc Diabetol. 2017;16(1):52.

48. Schwingshackl L, Hoffmann G. Mediterranean dietary pattern, inflammation and endothelial function: a systematic review and meta-analysis of intervention trials. Nutr Metab Cardiovasc Dis. 2014;24(9):929-39.

49. Black MA, Cable NT, Thijssen DH, Green DJ. Importance of measuring the time course of flow-mediated dilatation in humans. Hypertension. 2008;51(2):203-10.

\footnotetext{
Ready to submit your research? Choose BMC and benefit from:

- fast, convenient online submission

- thorough peer review by experienced researchers in your field

- rapid publication on acceptance

- support for research data, including large and complex data types

- gold Open Access which fosters wider collaboration and increased citations

- maximum visibility for your research: over $100 \mathrm{M}$ website views per year
}

At BMC, research is always in progress.

Learn more biomedcentral.com/submissions 